DOI: 10.17805/trudy.2017.5.2

\title{
МОЛОДЕЖЬ В СОВРЕМЕННОЙ РОССИИ: ПРОБЛЕМЫ И ПУТИ ИХ РЕШЕНИЯ
}

\author{
О. В. Ромашов
}

Московский государственный лингвистический университет

Аннотация: В статье рассматриваются существующие проблемы в формировании и воспитании молодого человека, роль в этом социокультурной среды вуза как необходимое условие профессионального становления молодого человека. Речь идет о процессе воспитания как специально организованном образе жизни с четко обозначенными целями, как необходимой и обязательной части для формирования социально активной личности.

Ключевые слова: молодежь; российская молодежь; проблемы воспитания; социокультурная среда; профессиональное становление; формирование личности

\section{YOUNG PEOPLE IN MODERN RUSSIA: THE PROBLEMS AND WAYS OF THEIR SOLUTION}

\author{
O. V. Romashov \\ Moscow State Linguistic University
}

\begin{abstract}
The article discusses the existing problems in the formation and education of a young man, the role that the socio-cultural environment of the university plays in it as a necessary condition of the professional formation of the young man. It implies the process of education as a specially organized way of life with clearly defined objectives as a necessary and indispensable part for the formation of a socially active person.

Keywords: young people; Russian youth; problems of education; sociocultural environment; professional development; personality formation
\end{abstract}

В России к молодежи относят молодых людей в возрасте от 14 до 30 лет включительно. Этот период молодых людей связан с получением образования, формированием личностных качеств и ценностных ориентаций. Формирование личностных качеств молодых людей процесс противоречивый. Он зависит от таких составляющих как: окружающая среда, 
общения, средств массовой коммуникации и соответственно от сформировавшихся потребностей и интересов молодых людей. Несмотря на то, что официально проводится целенаправленная молодежная политика де факто, мы получаем значительное количество молодых людей со сформированными разными нормами, ценностями и ценностными ориентациями (Ситаров, 2017).

Необходимо отметить, что большая часть молодежи ориентирована на общественно признанные нормы и ценности. Она ориентирована на получение достойного образования, трудоустройства и активного участия в общественной жизни страны. В частности в настоящее время получить высшее образование, как на бесплатной, так и платной основе не представляет собой сложную проблему. Если молодой человек не смог поступить в высшее учебное заведение на бюджетное место, то на выбор ему предоставляется довольно большое количество учебных заведений на платной основе. И сейчас довольно распространенное явление среди молодежи, имеющих два и более высших образования. И еще положительным является то, что молодым людям на обучение предоставляется льготный кредит, который они могут погасить уже работая.

Исходя из этого, у молодых людей формируются определенные положительные ценности, ориентированные на получение образования и поиска достойной этого образования работы. Именно на это ориентирует и государственная молодежная политика (Плотников, 2016: Электр. ресурс; Луков, 2016).

В то же время молодежь неоднородна. В молодежной среде много проблем. Она очень сильно реагирует на условия жизнедеятельности, материальный достаток, ущемление ее прав и даже на не внимание к молодежным проблемам. В связи с демографической ситуацией в России количество молодых людей в работоспособном возрасте из года в год сокращается (Ильинский, 2011). Так по переписи 1989 г. молодых людей в возрасте от 14 до 30 лет в Российской Федерации насчитывалось 34,4 млн человек или 23,4 \%. За десять лет с 1979 г. численность молодежи сократилось на 8 млн человек и эта тенденция продолжает развиваться.

По данным Росстата, в 2015 г. количество молодых людей в возрасте от 15 до 29 лет включительно составило 28,7 млн человек, то есть доля молодежи в общем количестве населения страны составила 19,6\%, в 2016 г. количество молодых людей в возрасте от 15 до 29 лет включительно составило 27,6 млн человек, а доля соответственно составила 18,8\%, в 2017 г. соответственно 26,4 млн, при этом доля - 17,9\% (Демография, Электр. ресурс). Как показывает статистика, доля молодых людей, занятых в народном хозяйстве постоянно снижается и особенно в таких отраслях, как промышленность, строительство и транспорт. Наблюдается отрицатель- 
ная структурная перестройка в экономике: все больше растет доля молодежи в непроизводственной сфере. А это требует внесение изменений в структуре ее подготовки и переподготовке.

Одна из проблем - это отсутствие регулирования министерством образования и науки бюджетных мест в технические и гуманитарные вузы. В настоящее время много выпускается менеджеров, юристов, управленцев, специалистов гуманитарных профессий и недостаточно специалистов технического профиля. И даже те, которые заканчивают высшее техническое учебное заведение чаще всего устраиваются после окончания вуза не по специальности.

Другая проблема - это низкая конкурентоспособность выпускников вуза. Во-первых, образование, которое они получают в вузе, не соответствует требованиям практики. Приступив к работе, выпускник вынужден снова учиться уже практическим трудовым навыкам. Такое отставание теоретических знаний от реальной практической деятельности часто связано с тем, что в вузах обучение в основном ориентировано на приобретение теоретических знаний. Во-вторых, в вузах занятия не ведут практические производственники. Приобретение практических навыков студенты получают только в процессе практик. Но этого недостаточно (Ромашова, 2015: Электр. ресурс).

В свое время, в середине 1990-х гг., социологи Научно-исследовательского центра Института молодежи г. Москвы, опросив 1875 молодых людей, выделили следующие главные проблемы российской молодежи: преступность, деньги, безработица, образование, досуг, здоровье, наркотики, проституция, права и Родина. Они и сегодня не только актуальны, но и значительно обострились. Рост преступности один из доминирующих факторов беспокойства молодежи.

Другой комплекс проблем, связанных с жизненными перспективами молодежи - это карьера, рост благосостояния, формирование семьи, которая становится в определенном возрасте особой ценностью. Особую озабоченность у молодых людей вызывает соблюдение гражданских, политических прав и свободы как провозглашенная ценность «новой России». Для большинства руководителей, политических деятелей неожиданным стало активное выступление молодежи не только школьной, но и студенческой, откликнувшейся на призыв Алексея Навального выйти на улицы с протестом, тем самым показав, что молодежь чувствует себя ущемленной в политических правах и демократических свободах. Особенно обострилась проблема между бедной и богатой молодежью.

В то же время все эти проблемы могут решаться при условии внимательного отношения к проблемам молодежи. Учитывая, что большинство молодых людей учится, необходимо особое внимание уделить обучаю- 
щейся молодежи. На формирование жизненных ценностей существенное влияние оказывает социокультурная среда школы, высшего учебного заведения (Ковалева, 2017). В качестве положительного примера можно привести Московский гуманитарный университет, представляющий собой учебный комплекс, отвечающий требованиям не только российским, но и западным стандартам. В процессе обучения в этом вузе у молодых людей формируются практически все необходимые для жизни в условиях рынка качества молодого человека. А социокультурная среда данного вуза представляет собой такое определенное социокультурное пространство, которое обеспечивает свободное творческое развитие студентов, формирование у них необходимых знаний, умений и навыков, профессиональных компетенций, которые обеспечивают им конкурентные преимущества в дальнейшей практической деятельности в условиях рынка.

Основной задачей социокультурной среды данного вуза становится не общее развитие всех качеств личности, а прежде всего, формирование у студенческой молодежи иной культуры отношений и поведения, профессионально-значимых качеств - специалиста, входящих в состав профессиональной компетентности, воспитание креативности, любознательности, воображения, упорства, умения работать в команде, самодисциплины и саморегуляции.

А в процессе преподавания всех без исключения дисциплин упор в университете делается на то, как данный предмет (дисциплина) может использоваться и применяться в практической деятельности. И, как результат, выпускники вуза после его окончания легко трудоустраиваются на приличную заработную плату с последующим продвижением по служебной лестнице.

В университете под руководством профессоров А. И. Ковалевой и Вал. А. Лукова в 2005-2009 гг. было проведено мониторинговое исследование, которое позволило зафиксировать исходный уровень социализации, приходящийся на период обучения в университете и сделать вывод о характере и масштабах влияния данного вуза на социальное становление своих студентов и выпускников (Луков, 2010).

В процессе обучения в вузе приходится преодолевать определенные барьеры, такие как: разная система ценностей у участников образовательного процесса, неодинаковые статусно-ролевое взаимодействие, часто и недостаточно высокий уровень мотивации к профессиональной деятельности и т.д. Для более эффективного функционирования учебного заведения в МосГу комплексно решаются существующие проблемы в следующих сферах деятельности вуза:

- в учебном процессе, включая научно-исследовательскую деятельность; 
- в организации и проведении всех видов практик;

- в организации отдыха, быта и досуга;

- в художественном и научно-техническом творчестве;

- в развитии физической культуры и спорта;

- в формировании здорового образа жизни.

Китайская пословица «Скажи мне - я забуду, покажи мне - я запомню, мотивируй меня - я пойму» выражает современные требования к процессу формирования и развитию молодого человека.

Сформированные в процессе обучения знания интегрируются в сознание (убеждение) соотносится с общественно признанным, принимается индивидом и реализуется в профессиональном поведении. Профессиональное поведение не должно противоречить нормам и правилам поведения, принятым в обществе.

Проблем у молодежи много. Как показывает практика, существенную роль в развитии и саморазвитии молодого человека в его гражданском становлении играют следующие факторы:

- приоритет в воспитательной деятельности, в формировании социально-активной молодежи;

- формирование у молодежи таких качеств как: креативность, созидательность, инициативность, способность самостоятельно принимать решения и брать на себя ответственность, мобильность;

- умение ориентироваться в мире труда и рыночной конъюнктуре;

- разрабатывать и внедрять новые и передовые технологии обучения, перенимать и внедрять передовой опыт, а также использовать его в подготовке будущего специалиста в современных условиях;

- готовить молодого человека применительно к меняющимся условиям жизнедеятельности, к конкурентной среде.

В поведение молодого человека обычно включены следующие компоненты:

- имиджевый компонент, под которым подразумевается не только форма одежды и внешний вид представителя конкретной профессии, но форма его делового общения;

- когнитивный компонент основывается на постоянном обучении, переобучении, повышении квалификации, так как без постоянного самообразования невозможна успешная профессиональная и социальная деятельность;

- вербальный - речевой компонент поведения молодежи является важнейшим компонентом межличностного общения и взаимодействия;

- воспитательный компонент поведения, реализуется путем общения, кураторства, шефства над молодыми людьми;

- социально-активный компонент реализуется в активном участии 
молодого человека во всех (особенно в производственной) сферах жизнедеятельности.

Все вышеперечисленные компоненты поведения, реализуемые в деятельности в сочетании с высоким уровнем знаний, умений и навыков позволяют говорить о социально активной молодежи.

Основными же качествами социально активной молодежи являются: целеустремленность, организованность, предприимчивость, социальная мобильность, коммуникабельность, креативность, эстетическая чувствительность, специальная компетентность, социально-правовая компетентность, аутокомпетентность.

Таким образом, поиск конкретных путей, средств и методов воспитания молодежи, учет личных социально-психологических характеристик молодого человека является важной социальной и практической задачей формирования и воспитания социально активной личности (Луков, 2017).

\section{СПИСОК ЛИТЕРАТУРЫ}

Демография [Электронный ресурс] // Федеральная служба государственной статистики. URL: http://www.gks.ru/wps/wcm/connect/rosstat main/rosstat/ru/statistics/population/demography/\# (дата обращения: 30.08.2017).

Ильинский, И. М. (2011) Куда идет отечественное образование // Знание. Понимание. Умение. № 1. С. 4-13.

Ковалева, А. И. (2017) Проблемы социализации личности студента в вузе // Знание. Понимание. Умение. № 3. С. 48-63. DOI: 10.17805/ zpu.2017.3.4

Луков, Вал. А. (2010) От развития личности до роста человеческого потенциала страны: возможный вклад российского высшего образования // Высшее образование для XXI века : VII междунар. науч. конференция. Москва, 18-20 ноября 2010 г. : Доклады и материалы. Сек. 5. Высшее образование и развитие человека. М. : Изд-во Моск. гуманит. ун-та. С. 3-10.

Луков, В. А. (2016) Молодежная политика : концепция И. И. Ильинского // Знание. Понимание. Умение. № 2. С. 13-24. DOI: 10.17805/ trudy.2016.2.2

Луков, В. А. (2017) Проблемы понимания и воспитания // Знание. Понимание. Умение. № 3. С. 31-46. DOI: 10.17805/trudy.2017.3.3

Плотников, А. Д. (2016) Молодежная политика в России: некоторые теоретические аспекты [Электронный ресурс] // Научные труды Московского гуманитарного университета. № 5. URL: http://journals.mosgu. ru/trudy/article/view/336 (дата обращения: 30.08.2017). DOI: 10.17805/ trudy.2016.5.5 
Ромашова, Л. О. (2015) Современное состояние рынка труда молодежи в России [Электронный ресурс] // Научные труды Московского гуманитарного университета. № 4. URL: http://journals.mosgu.ru/trudy/article/ view/48 (дата обращения: 30.08.2017). DOI: 10.17805/trudy.2015.4.4

Селиверстова, Н. А. (2015) Знания, умения и навыки как элементы образовательного опыта молодежи [Электронный ресурс] // Научные труды Московского гуманитарного университета. № 4. URL: http://journals. mosgu.ru/trudy/article/view/47 (дата обращения:30.08.2017).DOI: 10.17805/ trudy.2015.4.3

Ситаров, В. А. (2017) Ценностные трансформации современной российской молодежи // Знание. Понимание. Умение. № 2. С. 202-210. DOI: 10.17805/zpu.2017.2.15

Дата поступления: 20.09.2017 2.

Ромашов Олег Викторович - доктор философских наук, профессор, профессор кафедры «Связи с общественностью» Института международных отношений и социально политических наук Московского государственного лингвистического университета, Почетный работник высшего профессионального образования Российской Федерации. Адрес: 119034 Россия, г. Москва, ул. Остоженка, д. 38. Тел.: +7 (499) 245-33-23. Эл. адрес: OVR101@yandex.ru

Romashov Oleg Viktorovich, Doctor of Philosophy, Professor, Professor, Department of Public Relations, Institute of International Relations and Social and Political Sciences, Moscow State Linguistic University; Honorary Worker of Higher Professional Education of the Russian Federation. Postal address: 38, Ostozhenka St., Moscow, Russian Federation 119034. Tel.: +7 (499) 2453323. E-mail: OVR101@yandex.ru

\section{Для циттирования:}

Ромашов О. В. Молодежь в современной России: проблемы и пути их решения [Электронный ресурс] // Научные труды Московского гуманитарного университета. 2017. № 5. URL: http://journals.mosgu.ru/trudy/ article/view/564 DOI: 10.17805/trudy.2017.5.2 (дата обращения: дд.мм.гг.) 